\title{
Blood oxidative stress and antioxidant defense profile of White Stork Ciconia ciconia chicks reflect the degree of environmental pollution
}

\author{
Halyna Tkachenko, Natalia Kurhaluk \\ Department of Zoology and Animal Physiology, \\ Institute of Biology and Environmental Protection, \\ Pomeranian University in Słupsk, Arciszewskiego 22B, 76-200 Słupsk, Poland \\ e-mail: kurhaluk@apsl.edu.pl
}

\begin{abstract}
Oxidative stress biomarkers in the blood of White Stork Ciconia ciconia chicks were analyzed during their development in nests in polluted and control environments. The control, relatively pure, environment was the village of Kłopot, with no industrial plants within a radius of $150 \mathrm{~km}$. Blood samples were also collected in two polluted areas, including the suburban village of Czarnowo, located $20 \mathrm{~km}$ from the city of Zielona Góra (southwestern Poland) and an area near the town of Głogów, where a large Copper Manufacture is situated. We measured two markers of oxidative stress (2-thiobarbituric acid reactive substances (TBARS) and stable 2,4-dinitrophenyl hydrazine derivates of the oxidative modified carbonyl groups levels), as well as antioxidant defenses (superoxide dismutase, catalase, glutathione peroxidase and glutathione reductase activities, ceruloplasmin and total antioxidant capacity levels) in the blood samples. White Stork chicks from different environments are probably significantly susceptible to environmental conditions. In the unpolluted area, chicks showed lower lipid and protein oxidation levels, indicating that the variation in the pollution-induced oxidative stress among areas is dependent of environmental loads. Increased oxidative stress biomarkers can modify antioxidant defenses in chicks from various environments, principally causing increased glutathione peroxidase activity in chicks from polluted regions. Therefore, the use of oxidative stress biomarkers to assess the health and condition of chicks will be useful in future studies aiming to identify miscellaneous environmental loading.
\end{abstract}

Key words: Ciconia ciconia L., oxidative stress, antioxidant defenses, biomarkers, pollution.

\section{Introduction}

The White Stork is a species whose breeding success is determined by a significant influence of the environments - a change of trophic condition, environmental structure, weather conditions (Latus et al. 2000; Nowakowski 2003, 2006; Nowakowski \& Wasilewska 2006). The transformation of the environment, especially by the excessive intensification of agriculture, has resulted in a decline of stork population, and even total extinction in some countries (Tryjanowski et al. 2006). In the past few decades, grassland birds have declined faster, largely due to habitat threats such as the intensification of agriculture (Profus 2006). Presently, the situation for White Stork may deteriorate drastically (Tryjanowski et al. 2006). The White Stork is nesting in human settlements and feeding in rural areas, where more and more chemical agents protecting plants are used, may caused accumulation of toxins in the organisms of White Stork. This accumulation may influence the condition of individuals, and in consequence, also their survival and the rate of reproduction of the whole population (Orłowski et al. 2006). The use of biocides and excessive doses of chemical fertilizers cause also a decline of soil fauna (earthworms and insects), which constitute an important element of the White Stork diet (Profus 1991). 
In our previous investigation, we determined how heavy metal poisoning is related to metal-induced oxidative stress in White Stork chicks from regions of Poland with different levels of pollution (Kamiński et al. 2006a, $2007,2009 a, b)$. The results of our study showed that the concentrations of very toxic heavy metals (lead and cadmium) gradually increased during nestling development, and in polluted areas were about twice as high as in the control area (the Odra meadows area) (Kamiński et al. 2006a, 2007, 2009a, b). We found high levels of cadmium (2.2 $\mathrm{mg} \mathrm{kg}$ ) and lead (7.2 $\left.\mathrm{mg} \mathrm{kg}^{-1}\right)$ in chicks from Głogów, whereas the lowest levels were seen in chicks from Odra meadows (Cd $1.45 \mathrm{mg} \mathrm{kg}^{-1}, \mathrm{~Pb} 0.84 \mathrm{mg} \mathrm{kg}^{-1}$ ) (Kamiński et al. 2009a). This was probably due to the higher contamination of the soils in polluted areas with these heavy metals. As stated in reports of previous studies (Chłopecka et al. 1996; Kabala \& Singh 2001), toxic heavy metals were higher in soil samples from polluted environments in southwest Poland. Four soil profiles located near a copper smelter and refinery in Głogów were investigated to determine how the distributions and chemical fractions of $\mathrm{Cu}$, $\mathrm{Pb}$, and $\mathrm{Zn}$ as well as their mobility relate to soil properties. Contamination with heavy metals was primarily restricted to surface horizons, and the degrees of contamination were 7 to 115-fold for $\mathrm{Cu}, 30$-fold for $\mathrm{Pb}$, and 6-fold for $\mathrm{Zn}$ (Kabala \& Singh 2001). Concentrations of Cd, Pb, and $\mathrm{Zn}$ ranged from 0.5 to 105,14 to 7100 , and 20 to $10000 \mathrm{mg}$ per $\mathrm{kg}$ of soil, respectively (Chłopecka et al. 1996). The most consistent distribution patterns were found when the soil samples were grouped according to total metal content. The inferred relative mobilities of the metals and their redistribution among different fractions support the view that metals from anthropogenic sources are more mobile than those from the parent materials of the soil (Chłopecka et al. 1996). The toxic metals accumulated in nestlings during the growth period, mostly in bones and feathers, and their toxic effects on the organism intensified with age (Hoffman 2002; Hoffman et al. 2005, 2009, 2011).

Transition metals act as catalysts in the oxidative reactions of biological macromolecules, so the toxicities associated with these metals might be due to oxidative tissue damage (Ercal et al. 2001). Cells under oxidative stress display various dysfunctions because lesions cause various modifications to DNA bases, enhance lipid peroxidation, and alter cell homeostasis (Valko et al. 2005).

It is suggested that metal-induced oxidative stress in cells may be partially responsible for the toxic effects of heavy metals (Ercal et al. 2001). In many studies, a link between the susceptibilities of birds to heavy metal poisoning and oxidative stress was observed. The mechanisms producing the harmful effects of oxidative stress are complex with different biomolecular mechanisms associated with ecotoxicological and ecological aspects (Koivula \& Eeva 2010). Components of the antioxidant defense sys- tem have the widest scope and greatest potential for use as subcellular biomarkers of the contamination of birds with metals from the environment (Berglund et al. 2007, 2011; Hoffman 2002; Hoffman et al. 2005, 2009, 2011; Kamiński et al. 2009a; Kurhalyuk et al. 2006a, b; Kenow et al. 2008; Koivula et al. 2011; Martinez-Haro et al. 2011; Mateo et al. 2003; Mateo \& Hoffman 2001).

Hematological and biochemical research into the condition of birds can potentially indicate positive associations with miscellaneous environmental loads (Kamiński et al. 2006a, b). Antioxidants and their oxidation products are important indicators of oxidative stress induced by toxic chemicals from environment (Berglund et al. 2007, 2011; Hoffman 2002; Hoffman et al. 2005, 2009, 2011; Kamiński et al. 2009a, b; Kurhalyuk et al. 2006a, b; Kenow et al. 2008; Koivula et al. 2011; Martinez-Haro et al. 2011; Mateo et al. 2003; Mateo \& Hoffman 2001).

Therefore, we hypothesized that White Stork chicks from polluted areas (near a Copper Manufacture in Głogów) suffer higher oxidative stress than chicks from the suburbs and the area near Odra meadows. We then performed a study to analyze the changes in lipid peroxidation (the 2-thiobarbituric acid reactive substances content) and oxidatively modified protein levels (by checking for stable 2,4-dinitrophenyl hydrazine derivatives of carbonyl groups) as biomarkers of oxidative stress, as well as the antioxidant defense system (the activities of superoxide dismutase, catalase, glutathione peroxidase, and glutathione reductase, and the ceruloplasmin level) in the blood of White Stork Ciconia ciconia chicks in polluted (i.e., near to a Głogów Copper Manufacture) and suburban areas, as well as in the Odra meadows area (the control area).

\section{Materials and methods}

\subsection{The study area}

Blood samples were collected from young storks developing immediately near Odra meadows (Kłopot village; $52^{\circ} 07^{\prime} 56.3^{\prime} \mathrm{N}, 1^{\circ} 42^{\prime} 10.4^{\prime} \mathrm{E}$; southwestern Poland), henceforth called "Odra meadows", treated as the control environment (Tryjanowski et al. 2005). They were compared with blood samples from young storks at village Czarnowo (52 02'03.7'N, 14'57'24.7'E) located $20 \mathrm{~km}$ away from Zielona Góra (5156’26.1'N, 15³0’38.9'E; southwestern Poland), and treated as "Suburbs" area. We also took our investigations near Głogów (51³9’32.6”N, $\left.16^{\circ} 04^{\prime} 49.9^{\prime \prime} \mathrm{E}\right)$, where a copper smelter and refinery in Głogów is situated. Głogów Copper Manufacture produces copper and lead from lead fields; therefore we call these areas "Polluted area". A total of 189 White Stork chicks were surveyed in three breeding seasons from different nestles and different White Stork chicks, 2008, 2009, and 2010. 
The age of birds varied from 43 to 54 days. We studied 69 individuals from "Odra meadows", 68 from the "Suburbs", and 52 individuals from "Polluted area". Our behavioral observations of storks as well as physical examinations of the birds suggested that all were physically healthy. The experiments were conducted with the Guidelines of the European Union Council and the current laws in Poland, according to the Ethical Commission. To eliminate diurnal rhythm changes, all examinations started at 10 and ended at $12 \mathrm{am}$.

\subsection{Blood samples}

Chicks were retrieved from the nest and placed in individual ventilated cotton sacks. We collected $5 \mathrm{~mL}$ blood samples by puncturing the brachial veins of the stork chicks in less than 1 min using $5 \mathrm{~mL}$ syringes with $0.7 \varnothing$ needles, and transferred the samples to tubes with EDTA. Cotton balls with coagulant were used for stypsis at the injection site. After collecting the blood samples, the chicks were returned to their nests. The samples were kept in a chilled cooler before transporting them to the laboratory. The plasma was removed; the erythrocytes were washed three times with five volumes of saline solution and centrifuged at $3,000 \cdot \mathrm{g}$ for $10 \mathrm{~min}$. After centrifugation, the plasma samples were frozen at $-20{ }^{\circ} \mathrm{C}$ and stored one week until analysis. The plasma was used to determine 2-thiobarbituric acid reactive substances and oxidatively modified protein levels, the total antioxidant capacity, as well as catalase and ceruloplasmin activities. The hemolyzed erythrocytes were used to assay for superoxide dismutase (1:1000), glutathione reductase, and glutathione peroxidase $(1: 20)$ activity.

\subsection{Biomarker analysis}

Thiobarbituric acid (TBA), oxidized and reduced glutathione (GSSG and GSH), NADPH, and 5,5-dithiobis-2-nitrobenzoic acid, ethylenediaminetetraacetic acid (EDTA), thrichloroacetic acid (TCA), quercetin, hydrogen peroxide, ammonium molybdate, sodium aside, t-butylhydroperoxide, Tween 80, urea acid, 2,4-dinitrophenyl hydrazine (DNFH) were obtained from Fluka (Buchs, Switzerland). All other chemicals were of analytical grade. All enzymatic assays were carried out at $25 \pm 0.5^{\circ} \mathrm{C}$ using a Specol 11 spectrophotometer (Carl Zeiss Jena, Germany). The enzymatic reactions were started by adding the blood or plasma samples. The specific assay conditions are presented subsequently. Each sample was analyzed in triplicate.

\subsubsection{Thiobarbituric acid reactive substrates (TBARS) assay}

TBARS were measured using the method of Kamyshnikov (2004). Briefly, $2 \mathrm{~mL}$ of distilled water were added to $0.1 \mathrm{~mL}$ of plasma, $1 \mathrm{~mL}$ of $20 \%$ TCA, and $1 \mathrm{~mL}$ of $0.8 \%$ TBA reagent, and this mixture was boiled in a water bath at $95^{\circ} \mathrm{C}$ for $10 \mathrm{~min}$. The reaction was stopped by placing the tubes in ice-cold water. This mixture was then centrifuged at 3,000 $\mathrm{g}$ for $10 \mathrm{~min}$. The absorbance of the supernatant was read at $540 \mathrm{~nm}$. The TBARS content was calculated using $1.56 \times 10^{5} \mathrm{mM}^{-1} \mathrm{~cm}^{-1}$ as the extinction coeffcient. The TBARS level was expressed in micromoles of malonic dialdehyde (MDA) per liter of plasma.

\subsubsection{The carbonyl derivatives content of protein oxidative modification (OMP) assay}

The oxidatively modified protein level was estimated by reacting the resulting carbonyl derivatives of amino acids with 2,4-dinitrophenylhydrazine (DNFH), as described by Levine et al. (1990) and modified by Dubinina et al. (1995). Briefly, 0.1 M DNPH (dissolved in $2 \mathrm{M} \mathrm{HCl}$ ) was added to $0.1 \mathrm{~mL}$ of the plasma after denaturing the proteins with $20 \%$ trichloracetic acid. After adding the DNPH solution (or $2 \mathrm{M} \mathrm{HCl}$ to the blanks), the tubes were incubated for a period of $1 \mathrm{~h}$ at $37^{\circ} \mathrm{C}$. The tubes were spun in a centrifuge for $20 \mathrm{~min}$ at $3,000 \mathrm{~g}$. After centrifugation, the supernatant was decanted and $1 \mathrm{~mL}$ of ethanol-ethylacetate solution was added to each tube. After mechanically disrupting the pellet, the tubes were allowed to stand for $10 \mathrm{~min}$ and then spun again (20 min at 3,000 g). The supernatant was decanted and the pellet washed with ethanol-ethylacetate twice more. After the final wash, the protein was solubilized in $2.5 \mathrm{~mL}$ of $8 \mathrm{M}$ urea solution. To speed up the solubilization process, the samples were incubated at $90{ }^{\circ} \mathrm{C}$ in a water bath for 5-10 min. The final solution was centrifuged to remove any insoluble material. The carbonyl content was calculated from absorbance measurements at 370 and $430 \mathrm{~nm}$ and using an absorption coeffcient of 22,000 $\mathrm{M}^{-1} \cdot \mathrm{cm}^{-1}$. Carbonyl groups were determined spectrophotometrically from the absorbance at $370 \mathrm{~nm}$ (aldehyde derivatives, $\mathrm{OMP}_{370}$ ) and $430 \mathrm{~nm}$ (ketonic derivatives, $\mathrm{OMP}_{430}$ ) and expressed in nanomoles per milliliter of blood.

\subsubsection{Superoxide dismutase activity assay}

Superoxide dismutase (SOD, EC 1.15.1.1) activity in the supernatant was determined according to Kostiuk et al. (1990). SOD activity was assessed according to its ability to dismutate superoxide produced during quercetin autoxidation in an alkaline medium ( $\mathrm{pH} 10.0)$. Briefly, $1.0 \mathrm{~mL}$ of $\mathrm{C}$ reagent was mixed with $0.1 \mathrm{~mL}$ of hemolyzed erythrocytes $(1: 1000)$. $\mathrm{C}$ reagent (a mixture of equal volumes 
of $0.1 \mathrm{M} \mathrm{K}$, Na phosphate buffer with $\mathrm{pH} 7.8$, and $0.08 \mathrm{M}$ EDTA) was created ex tempore; $\mathrm{pH}$ of the $\mathrm{C}$ reagent was adjusted to 10.0 by adding tetramethylenediamine. Distilled water $(0.1 \mathrm{~mL})$ was added to the blank vials instead of sample. The total volume of the sample was brought up to $2.4 \mathrm{~mL}$ using distilled water. The reaction was initiated by adding $0.1 \mathrm{~mL}$ of quercetin $(1.4 \mu \mathrm{M}$ dissolved in dimethyl sulfoxide). The absorbance at $406 \mathrm{~nm}$ was measured at the start of the reaction and after $20 \mathrm{~min}$. Activity was expressed in units of SOD per milliliter of blood.

\subsubsection{Catalase activity assay}

Catalase (CAT, EC 1.11.1.6) activity was determined by measuring the decrease in $\mathrm{H}_{2} \mathrm{O}_{2}$ in the reaction mixture using a spectrophotometer at a wavelength of $410 \mathrm{~nm}$ by the method of Koroliuk et al. (1988). The reaction was initialized by adding $0.1 \mathrm{~mL}$ of the plasma sample to the incubation medium ( $2 \mathrm{~mL}$ of $0.03 \% \mathrm{H}_{2} \mathrm{O}_{2}$ solution). The duration of this reaction was $10 \mathrm{~min}$ at room temperature. The reaction was terminated by rapidly adding $1.0 \mathrm{~mL}$ of $4 \%$ ammonium molybdate (dissolved in $12.5 \mathrm{mM} \mathrm{H}_{2} \mathrm{SO}_{4}$ ) and $1 \mathrm{~mL}$ of $125 \mathrm{mM} \mathrm{H}_{2} \mathrm{SO}_{4}$. All samples were centrifuged at $3,000 \cdot \mathrm{g}$ for $5 \mathrm{~min}$. The absorbance of the obtained solution was measured at $410 \mathrm{~nm}$ and was compared with that of the blank. One unit of catalase activity was defined as the amount of enzyme required to decompose $1 \mu \mathrm{mol} \mathrm{H}_{2} \mathrm{O}_{2}$ per minute per liter of plasma.

\subsubsection{Glutathione reductase activity assay}

Glutathione reductase (GR, EC 1.6.4.2) activity in the blood was measured according to the method described by Glatzle et al. (1974). The enzymatic activity was assayed spectrophotometrically by measuring NADPH consumption. In the presence of GSSG and NADPH, GR reduces GSSG and oxidizes NADPH, resulting in a decrease of the absorbance at $340 \mathrm{~nm}$. The enzyme assay mixture contained $2.4 \mathrm{~mL}$ of $67 \mathrm{mM}$ sodium phosphate buffer ( $\mathrm{pH} 6.6$ ), $0.2 \mathrm{~mL}$ of $7.5 \mathrm{mM}$ oxidized glutathione, and $0.1 \mathrm{~mL}$ of hemolyzed erythrocytes $(1: 20)$. The rate of NADPH oxidation was followed spectrophotometrically at $340 \mathrm{~nm}$. Quantification was performed based on a molar extinction coefficient of $6.22 \mathrm{mM}^{-1} \cdot \mathrm{cm}^{-1}$ of NADPH. A blank without NADPH was used and the GR activity was expressed in nanomoles of NADPH per minute per milliliter of blood.

\subsubsection{Glutathione peroxidase activity assay}

Glutathione peroxidase (GPx, EC 1.11.1.9) activity was determined by detecting the nonenzymatic utilization of GSH (the reacting substrate) at an absorbance of $412 \mathrm{~nm}$ after incubation with 5,5-dithiobis-2-nitrobenzoic acid (DTNB) according by the method of Moin (1986). The assay mixture contained $0.8 \mathrm{~mL}$ of $0.1 \mathrm{M}$ Tris- $\mathrm{HCl}$ buffer with $6 \mathrm{mM}$ EDTA and $12 \mathrm{mM}$ sodium azide ( $\mathrm{pH} 8.9)$, $0.1 \mathrm{~mL}$ of $4.8 \mathrm{mM}$ GSH, $0.2 \mathrm{~mL}$ of hemolyzed erythrocytes $(1: 20), 1 \mathrm{~mL}$ of $20 \mathrm{mM}$ t-butylhydroperoxide, and $0.1 \mathrm{~mL}$ of $0.01 \mathrm{M}$ DTNB. The rate of GSH reduction was followed spectrophotometrically at $412 \mathrm{~nm}$. GPx activity was expressed in nanomoles of GSH per minute per milliliter of blood.

\subsubsection{The ceruloplasmin level assay}

The ceruloplasmin (CP, EC 1.16.3.1) level in the plasma was measured spectrophotometrically at $540 \mathrm{~nm}$, as described by Ravin (1961). The assay mixture contained $0.1 \mathrm{~mL}$ of plasma, $0.4 \mathrm{M}$ sodium acetate buffer ( $\mathrm{pH} 5.5)$, and $0.5 \%$ p-phenylenediamine. The mixture was incubated at $37{ }^{\circ} \mathrm{C}$ for $60 \mathrm{~min}$. Before cooling at $4{ }^{\circ} \mathrm{C}$ for $30 \mathrm{~min}$, the mixture was added to $3 \%$ sodium fluoride for inhibition. Ceruloplasmin was expressed in milligrams per liter of plasma.

\subsubsection{Total antioxidant capacity assay}

The TAC level in the plasma was estimated by measuring the TBARS level following Tween 80 oxidation. This level was determined spectrophotometrically at $532 \mathrm{~nm}$ (Galaktionova et al. 1998). Plasma inhibits the $\mathrm{Fe}^{2+} /$ ascorbate-induced oxidation of Tween 80 , resulting in a decrease in the TBARS level. Briefly, $0.1 \mathrm{~mL}$ of plasma sample were added to $2 \mathrm{~mL}$ of $1 \%$ Tween 80 reagent, $0.2 \mathrm{~mL}$ of $1 \mathrm{mM}$ $\mathrm{FeSO}_{4}$, and $0.2 \mathrm{mM}$ of $10 \mathrm{mM}$ ascorbic acid. In the blank assay, $0.1 \mathrm{~mL}$ of distilled water was used instead of the sample. The mixture was heated in a boiling water bath for $48 \mathrm{~h}$ at $37^{\circ} \mathrm{C}$. After cooling, $1 \mathrm{~mL}$ of TCA was added. The mixture was centrifuged at $3,000 \cdot \mathrm{g}$ for $10 \mathrm{~min}$. After centrifugation, $2 \mathrm{~mL}$ of supernatant and $2 \mathrm{~mL}$ of $0.25 \%$ of TBA reagent were mixed. The mixture was heated in a boiling water bath at $95{ }^{\circ} \mathrm{C}$ for $15 \mathrm{~min}$. The absorbance of the obtained solution was measured at $532 \mathrm{~nm}$. The absorbance of the blank was defined as $100 \%$. The level of TAC in the sample (\%) was calculated with respect to the absorbance of the blank.

\subsection{Statistical analysis}

Results are expressed as mean \pm S.E.M. Data from three years were collected and summarized. Kolmogorov-Smirnov test was applied to evaluate normality while Levene test was used to test the homogeneity of variance. As most of the distributions deviated from the normal distribution, non-parametric tests were used for further analyses. In order to find significant differences (significance level, $\mathrm{p}<0.05$ ) between "Odra meadows", "Suburbs", and "Polluted area" groups, Kruskal-Wallis one-way analy- 
sis of variance by ranks test was applied to the data with post-hoc mean rank multiple comparison (Dunn test) (Zar 1999). All statistical analyses were performed using STATISTICA 8.0 software (StatSoft, Poland).

\section{Results}

The lipid peroxidation levels in the plasma of White Stork chicks from different Poland environments are summarized in Figure 1. TBARS levels $(\mathrm{H}=142.52, \mathrm{P}<0.0001)$ in chicks from the "Suburbs" and the "Polluted area" were significantly higher than those in chicks from "Odra meadows", by $69 \%(\mathrm{P}<0.0001)$ and $112 \%(\mathrm{P}<0.0001)$, respectively. TBARS levels in chicks from the "Polluted area" were significantly higher than those in chicks from suburbs by $26 \%(\mathrm{P}<0.0001)$.

The effects of the various ecological threats present in particular environments on the oxidatively modified pro-

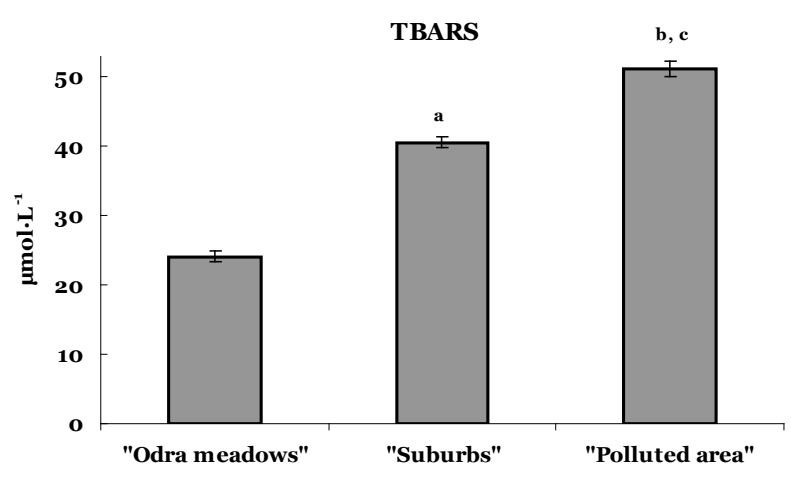

Figure 1. The level of lipid peroxidation determined by quantifying the concentration of 2-thiobarbituric acid reactive substrates (TBARS) ( $\left.\mu \mathrm{mol} \mathrm{MDA} \cdot \mathrm{L}^{-1}\right)$ in the blood of White Stork Ciconia ciconia chicks from control ("Odra meadows") and polluted environment ("Suburbs", "Polluted area").

Values expressed as mean \pm S.E.M.

Results of Kruskal-Wallis test with post-hoc mean rank multiple comparison:

a - the significant change was shown as $\mathrm{P}<0.05$ when compared between "Odra meadows" and "Suburbs areas" group values;

b - significant difference $(\mathrm{P}<0.05)$ between "Odra meadows" and "Polluted area" group values;

c - significant difference $(\mathrm{P}<0.05)$ between "Suburbs areas" and "Polluted area" group values tein content of the plasma, as measured as carbonyl oxidation levels, are shown in Figure 2. Aldehyde $(\mathrm{H}=78.28$, $\mathrm{P}<0.0001)$ and ketonic $(\mathrm{H}=33.32, \mathrm{p}<0.0001)$ derivatives of carbonyl oxidation levels were higher in plasma of chicks from the "Polluted area" than in plasma of chicks from "Odra meadows" by $59 \%(\mathrm{P}<0.0001)$ and by $22 \%$ $(\mathrm{P}<0.0001)$, respectively. The carbonyl oxidation levels in chicks from the "Suburbs" were significantly higher than those in the control group ("Odra meadows") by $24 \%(\mathrm{P}<$ $0.0001)$ and $8 \%(\mathrm{P}<0.0001)$ for the aldehyde and ketonic derivatives, respectively.

Activities of antioxidant enzymes are shown in Table 1. Higher SOD activities $(\mathrm{H}=40.09, \mathrm{P}<0.0001)$ were found in chicks from "Odra meadows" and the "Polluted area" than in those from the "Suburbs", by 29\% $(\mathrm{P}<0.0001)$ and $24 \%(\mathrm{P}<0.0001)$, respectively. Plasma CAT activity $(\mathrm{H}=$ $58.27, \mathrm{P}<0.0001)$ was higher in chicks from the "Suburbs" and the "Polluted area" than in chicks from "Odra meadows", by $52 \%(\mathrm{P}<0.0001)$ and by $47 \%(\mathrm{P}<0.0001)$,
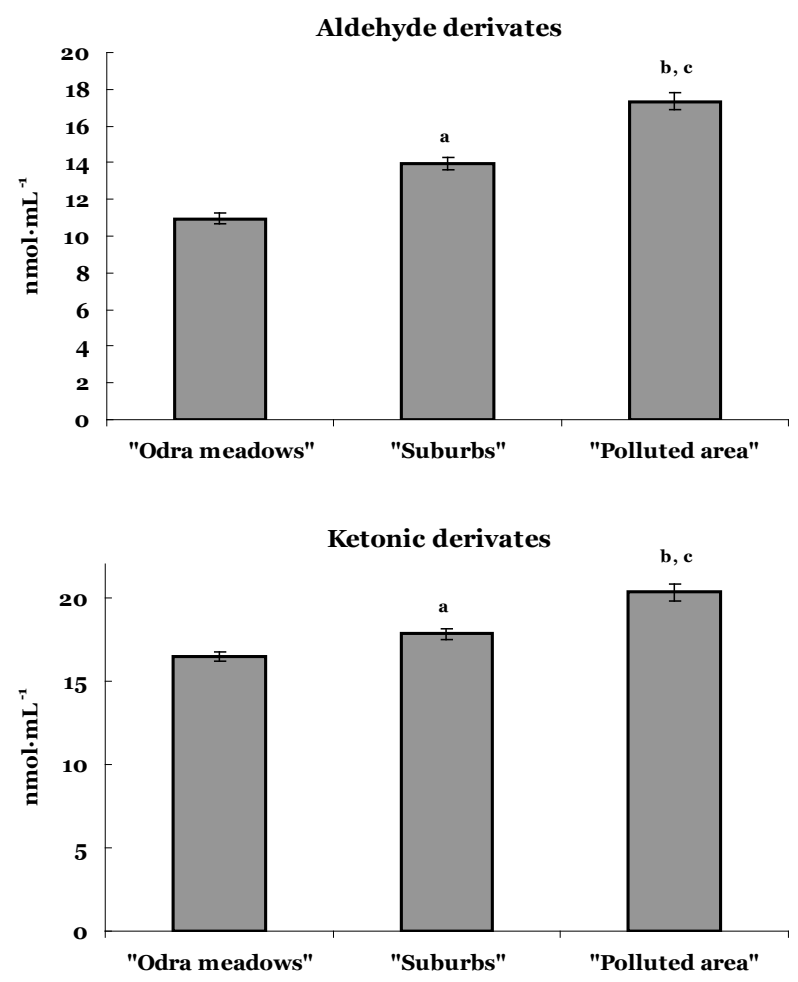

Figure 2. Oxidatively modified proteins (OMP) content, measured by quantity of carbonyl oxidation $\left(\mathrm{nmol} \cdot \mathrm{mL}^{-1}\right)$ in the blood of White Stork Ciconia ciconia chicks from control ("Odra meadows") and polluted environment ("Suburbs", "Polluted area"). Carbonyl groups were determined spectrofotometrically from the difference in absorbance at 370 (aldehyde derivates) and $430 \mathrm{~nm}$ (ketonic derivates). Data are means \pm S.E.M.; ${ }^{a}$, b and ${ }^{\mathrm{c}}$ - see Figure 1 
Table 1. Activities of antioxidant enzymes in the blood of White Stork Ciconia ciconia chicks from control ("Odra meadows") and polluted environment ("Suburbs", "Polluted area"). Data are means \pm S.E.M.

\begin{tabular}{|c|c|c|c|}
\hline Antioxidant enzymes activity & "Odra meadows" & "Suburbs" & "Polluted area" \\
\hline $\mathrm{SOD}, \mathrm{U} \cdot \mathrm{mL}^{-1}$ & $585.20 \pm 17.95$ & $452.39 \pm 11.93^{\mathrm{a}}$ & $559.96 \pm 8.03^{\mathrm{c}}$ \\
\hline $\mathrm{CAT}, \mu \mathrm{mol} \cdot \mathrm{min}^{-1} \cdot \mathrm{L}^{-1}$ & $1.13 \pm 0.04$ & $1.72 \pm 0.06^{\mathrm{a}}$ & $1.66 \pm 0.07^{\mathrm{b}}$ \\
\hline $\mathrm{GR}, \mathrm{nmol} \mathrm{GSH} \cdot \mathrm{min}^{-1} \cdot \mathrm{mL}^{-1}$ & $22.44 \pm 0.43$ & $11.12 \pm 0.31^{\mathrm{a}}$ & $17.53 \pm 0.49^{b c}$ \\
\hline GPx, nmol NADPH ${ }_{2} \cdot \mathrm{min}^{-1} \cdot \mathrm{mL}^{-1}$ & $773.13 \pm 16.02$ & $975.30 \pm 133.08$ & $5463.07 \pm 126.01^{b c}$ \\
\hline $\mathrm{CP}, \mathrm{mg} \cdot \mathrm{L}^{-1}$ & $31.66 \pm 0.97$ & $31.71 \pm 1.03$ & $18.56 \pm 0.81^{\mathrm{bc}}$ \\
\hline
\end{tabular}

${ }^{\mathrm{a}},{ }^{\mathrm{b}}$, and $^{\mathrm{c}}-$ see Figure 1

respectively. The GR activity $(\mathrm{H}=130.60, \mathrm{P}<0.0001)$ was significantly higher in chicks from Odra meadows than in chicks from the suburbs and the polluted area (by $102 \%$, $\mathrm{p}=0.0001$ and $28 \%, \mathrm{p}=0.0001$, respectively). Regarding GPx $(\mathrm{H}=107.97, \mathrm{p}=0.0001)$, its activity was increased by 7.1 - and 5.6 -fold $(\mathrm{P}<0.0001)$ in chicks from the "Polluted area" compared to the values for chicks from "Odra meadows" and the "Suburbs". The CP level $(\mathrm{H}=74.9, \mathrm{P}$ $<0.0001$ ) was significantly higher in the plasma of chicks from "Odra meadows" and the "Suburbs" than in the blood of chicks from the "Polluted area", by $70.6 \%(\mathrm{P}<0.0001)$ and $70.9 \%(\mathrm{P}<0.0001)$, respectively. Plasma total antioxidant capacity $(\mathrm{H}=92.43, \mathrm{P}<0.0001)$ was significantly lower in chicks from the "Polluted area" than in chicks from the "Suburbs" and "Odra meadows", by $26.5 \%(\mathrm{P}<$ $0.0001)$ and $20 \%(\mathrm{P}<0.0001)$, respectively (Fig. 3).

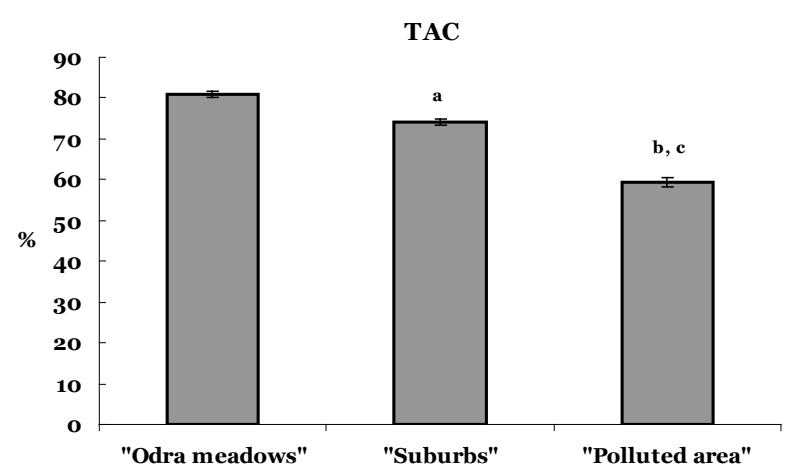

Figure 3. Total antioxidant capacity (\%)in the blood of White Stork Ciconia ciconia chicks from control ("Odra meadows") and polluted environment ("Suburbs", "Polluted area").

Data are means \pm S.E.M.

${ }^{\mathrm{a}},{ }^{\mathrm{b}}$, and ${ }^{\mathrm{c}}-$ see Fig. 1.

\section{Discussion}

Our results indicate changes in oxidative stress biomarkers, as well as selected antioxidant defenses parameters (SOD, CAT, GR, and GPx activities, CP and TAC levels) in the blood of chicks in response to environmental contamination. The use of biomarkers offers invaluable early warning information to be used to improve the processes of hazard assessment for populations and ecological risk assessment (Martinez-Gomez et al. 2010). Results of this study show that nestlings of White Storks in metal contaminated areas (such as the polluted area near Głogów Copper Manufacture) are affected by oxidative stress, given as increased lipid peroxidation, oxidatively modified protein contents, and antioxidant defenses (Figs 1-3, Table 1). We found significant increase of oxidative stress biomarkers in the blood of chicks from the polluted environments (Fig. 1 and 2). Significant decrease in TAC level in the blood of chicks from the "Suburbs" and "Polluted area" was found (Fig. 3). We conclude that oxidatively modified protein contents and lipid peroxidation levels may function as useful biomarkers for oxidative stress in White Stork nestlings exposed to metal contaminated environments. Our results can indicate that the consequence of higher environmental contamination is a more intense oxidative stress in the blood of chicks.

It is important to note the predominance of lead and cadmium participation in element-enzyme and element-enzyme interactions in the blood of young storks in our previous studies. The concentrations of micro- and macroelements, as well as toxic heavy metals ( $\mathrm{Pb}$ and $\mathrm{Cd}$ ) were higher in the blood of chicks from polluted and suburban environments than in those nesting near Odra meadows (Kurhalyuk et al. 2006a, b; Kamiński et al. 2006a, b, 2007, 2009a, b).

Recent toxicological studies have reported that lead and cadmium exposure is capable of generating reactive oxygen species (ROS) such as hydroxyl radical (HO), superoxide radical $\left(\mathrm{O}_{2}^{-}\right)$or hydrogen peroxide $\left(\mathrm{H}_{2} \mathrm{O}_{2}\right)$ and inducing 
oxidative damage to the brain, heart, kidneys, and reproductive organs with neurological, haematological, gastrointestinal, reproductive, circulatory, and immunological pathologies (Koizumi et al. 1996; Ercal et al. 2001; Valko et al. 2005). Transition metals act as catalysts in the oxidative reactions of biological macromolecules and deplete cells' major antioxidants, particularly thiol-containing antioxidants and enzymes. Therefore, the toxicities associated with these metals might be due to oxidative tissue damage (Ercal et al. 2001). It is suggested that lead and cadmium induced oxidative stress in cells can be partially responsible for the toxic effects of heavy metals. Cells under oxidative stress display various dysfunctions due to lesions caused by ROS to lipids, proteins and DNA (Ercal et al. 2001; Valko et al. 2005).

Lipid peroxides, formed by the attack of radicals on polyunsaturated fatty acid residues of phospholipids, can further react with redox metals finally producing toxic malondialdehyde, 4-hydroxynonenal and other exocyclic DNA adducts (Valko et al. 2005). Lipid peroxidation may cause cross-linking and polymerization of membrane components. In this way, cell membranes may be modified in their lipid composition and thus in cellular functions (Koizumi et al. 1996). Proteins are major targets for ROS in cells and oxidized proteins that accumulate during oxidative stress and in some pathological conditions (Berlett \& Stadtman 1997; Stadtman \& Berlett 1997). Exposure of proteins to ROS results in modification of amino acid residues, which alters protein structure and function (Berlett \& Stadtman 1997; Yeh et al. 2008). Therefore, protein carbonyls have been used as a biomarker of oxidative stress (Yeh et al. 2008). In accordance with this, we can consider that strict relationships exist among various nest locations on contaminated areas by toxic heavy metals, regarding their participation in the modification of lipids and proteins, as well as antioxidant defenses. We noted that White Stork nestlings in heavy metal contaminated areas are accompanied by an increase in lipid and protein oxidation (Fig. 1 and 2). Thus, young storks are probably significantly susceptible to environmental conditions. They demonstrated initiation of lipid peroxidation and protein oxidation. Chicks of White Storks, developing along a pollution gradient, might differ in their compensatory capacity for effective elimination of prooxidative toxicity of heavy metals and many organic pollutants. Our results show that the blood of chicks from the "Polluted area" was more susceptible to oxidative stress due to lipid and protein oxidation, manifested as TBARS and protein carbonyls, respectively, than those of chicks from the "Suburbs" and "Odra meadows" (Fig. 1 and 2). Our results can indicate that perhaps there is a dose-response relationship between the level of environment contamination and oxidative stress in the nestlings in the polluted area.
We summarized that increased lipid peroxidation modifies antioxidant enzyme activity and causes changes in the antioxidant defense system in the blood of chicks from various environments, principally causing increased enzyme activity in the blood of chicks from polluted regions (Table 1). In environments with high levels of anthropogenic pollution, antioxidants are important to protect the body from elevated oxidative stress (Isaksson et al. 2008). The maintenance of a high antioxidant capacity in cells may increase tolerance against different types of environmental stress (Thomas et al. 1999). In our study, GPx activity was strongly higher in the polluted environment due to subsequently higher level of oxidative stress in the nestlings in the polluted area (Table 1). Koivula et al. (2011) also noted high GPx activity in the Great Tit from the polluted area.

Glutathione (GSH) is the major cellular thiol participating in cellular redox reactions and thioether formation (Sies 1999). It is mainly involved in detoxication mechanisms through conjugation reactions. Other functions include thiol transfer, destruction of free radicals and metabolism of various exogenous and endogenous compounds (Rana et al. 2002). During oxidative stress, GSH plays a key role of protection and detoxification as a cofactor of glutathione peroxidases and glutathione-S-transferases (Gerard-Monnier \& Chaudiere 1996). The reduced form of glutathione (GSH) and its associated enzymes are the most reliable biomarkers directly related to assessment of metal-induced oxidative stress (Isaksson 2010). Glutathione dependent enzymes, i.g. glutathione-S-transferases (GST), glutathione peroxidases, glutathione reductase and gamma-glutamate transpeptidase facilitate protective manifestations (Rana et al. 2002). GR plays an indirect but essential role in the prevention of oxidative damage within the cell by helping to maintain appropriate levels of intracellular GSH. GSH, in conjunction with the GPx, is the acting reductant responsible for minimizing harmful hydrogen peroxide cellular levels (Meister 1994). GPx acts on lipid hydroperoxide substrates that are released from membrane phospholipids (Van Kuijk et al. 1987). There are synergistic interactions between GSH and other components of the antioxidant defense system such as vitamin C, vitamin E and superoxide dismutases (Gerard-Monnier \& Chaudiere 1996). Thus GPx can be used as an indicator of increased oxidative stress. The activity of this enzyme was, however, not directly related to metal exposure, but more likely to some secondary pollution-related change in the nestling condition (Koivula et al. 2011).

Our study is in agreement with studies obtained by other researchers. For example, Berglund et al. (2007) also investigated whether Pied Flycatcher Ficedula hypoleuca nestlings in the pollution gradient of the industry were affected by oxidative stress. They used antioxidant molecules and enzyme activities as biomarkers for oxidative stress 
in the liver tissue of free-living Pied Flycatcher nestlings exposed to metal contaminated environments (the smelter was located in the northern part of Sweden). Nestlings in metal contaminated areas showed signs of oxidative stress by up regulated hepatic antioxidant defense, slightly elevated lipid peroxidation and antioxidant defenses while simultaneously accumulating amounts of arsenic, cadmium, mercury, lead, iron and zinc in their liver tissue (Berglund et al. 2007). Rainio et al. (2013) studied species-specific variation in the oxidative status and antioxidant defenses of Great Tit Parus major, Blue Tit Cyanistes caeruleus and Pied Flycatcher nestlings in a vicinity of a non-ferrous smelter. They founded a strong evidence of interspecific variation in CAT and SOD activities, whereas less variation was observed in parameters related to glutathione metabolism (Rainio et al. 2013). Koivula et al. (2011) submitted the most reliable biomarkers to detect pollution-related oxidative stress in wild birds by comparing oxidative stress status in in Great Tit nestlings at populations in polluted and unpolluted areas. Antioxidants (GSH, carotenoids) and several antioxidant enzymes (GPx, GR, SOD, and CAT) as indicators of the oxidative stress were used in their study (Koivula et al. 2011). Also Isaksson et al. (2009) compared oxidative damage (TBARS level) and different antioxidant enzymes in lungs and liver tissue of urban and rural Great Tits.

Inhibition of antioxidant enzymes and interactions with sulfhydryl groups of proteins may play a more important role in the lead poisoning of waterfowl than lipid peroxidation (Mateo et al. 2003). Lead exposure inhibited GPx activity in plasma, liver, and brain, and decreased protein thiols in blood and liver of mallards during the first week of lead exposure. $\mathrm{Pb}$-induced pathological changes associated with hepatic and nervous function were significantly correlated with lower GPx activity and protein thiol concentrations in these tissues rather than lipid peroxidation (Mateo et al. 2003). Lead exposure resulted in an increase in tissue lipid peroxides and variations in glutathione concentrations for the first 6 weeks in the young of two species of waterfowl, Canada Goose Branta canadensis and Mallard Anas platyrhynchos. Both species showed a rise in hepatic GSH concentration with lead exposure, and the relationship between increased lipid peroxidation and lead exposure was significant in geese (Mateo \& Hoffman 2001). Berglund et al. (2011) measured the concentrations of several elements (arsenic, calcium, cadmium, copper, nickel, lead, selenium, and zinc) in adult and nestling Pied Flycatchers and Great Tits at different distances from a $\mathrm{Cu}-\mathrm{Ni}$ smelter. Feces of nestlings generally failed to correlate with internal element concentrations but they did reflect the exposure of the nestlings to pollution, indicating increased stress due to the need to remove excess metals. Uptake of $\mathrm{Cu}$ and $\mathrm{Ni}$ were regulated, but $\mathrm{As}, \mathrm{Cd}, \mathrm{Pb}$, and $\mathrm{Se}$ accumulated in liver tissue. The accumulation of $\mathrm{As}$ and $\mathrm{Pb}$ in Pied Flycatcher livers was explained by more effcient absorption, whereas the high $\mathrm{Cd}$ concentration was primarily due to different intakes through food items. Both $\mathrm{Cd}$ and Se accumulated with age (Berglund et al. 2011). Our previous results also indicate that increased oxidative stress modifies antioxidant enzyme activity and causes changes in antioxidant defenses in chicks from various environments, principally causing increased enzyme activity in chicks from polluted regions (Kamiński et al. 2009a, b).

We can conclude from our results, that the regions of White Stork nesting with various ecological threats are also responsible for enhanced oxidative damage and decrease total antioxidant capacity, estimated by TBARS and carbonyl derivatives of amino acids reaction (Fig. 1 and 2) and modified antioxidant defenses (Table 1, Fig. 3). The use of hematological research assesses the condition of the birds and gives positive association with miscellaneous environmental loads.

In conclusion, it was found that White Stork chicks from different environments are probably significantly susceptible to environmental conditions. In the unpolluted area, chicks showed lower lipid and protein oxidation levels, indicating that the variation in the pollution-induced oxidative stress among areas is dependent of environmental loads. Increased oxidative stress biomarkers can modify antioxidant defenses in chicks from various environments, principally causing increased GPx activity in chicks from polluted regions. Therefore, the use of oxidative stress biomarkers to assess the health and condition of chicks will be useful in future studies aiming to identify miscellaneous environmental loading.

\section{Acknowledgements}

The authors wish to thank Prof. Leszek Jerzak and Prof. Mariusz Kasprzak, who allowed us to take samples for biochemical analysis. This study was supported by a grant for young scientists from Pomeranian University in Słupsk (2011-2012).

\section{References}

Berglund A. M., Koivula M. J. \& Eeva T., 2011, Speciesand age-related variation in metal exposure and accumulation of two passerine bird species, Environmental Pollution 159(10): 2368-2374.

Berglund A. M., Sturve J., Förlin L. \& Nyholm N. E., 2007, Oxidative stress in pied flycatcher (Ficedula hypoleuca) nestlings from metal contaminated environments in northern Sweden, Environmental Research 105(3): 330-339. 
Berlett B. S. \& Stadtman E. R., 1997, Protein oxidation in aging, disease, and oxidative stress, Journal of Biological Chemistry 272: 20313-20316.

Chłopecka A., Bacon J. R., Wilson M. J. \& Kay J., 1996, Forms of cadmium, lead, and zinc in contaminated soils from south west Poland, Journal of Environmental Quality 25: 69-79.

Dubinina E. E., Burmistrov S. O., Khodov D. A. \& Porotov I. G., 1995, Oxidative modification of human serum proteins. A method of determining it, Voprosy Meditsinskoi Khimii 41: 24-26.

Ercal N., Gurer-Orhan H. \& Aykin-Burns N., 2001, Toxic metals and oxidative stress part I: mechanisms involved in metal induced oxidative damage, Current Topics in Medicinal Chemistry 1: 529-539.

Galaktionova L. P., Molchanov A. V., Elchaninova S. A. \& Varshavskiy B., 1998, Lipid peroxidation in patients with gastric and duodenal ulcers, Klinicheskaia Labaratornaia Diagnostika 6: 10-14.

Gérard-Monnier D. \& Chaudiere J., 1996, Metabolism and antioxidant function of glutathione, Pathologie Biologie 44(1): 77-85.

Glatzle D., Vuilleumier J. P., Weber F. \& Decker K., 1974 Glutathione reductase test with whole blood, a convenient procedure for the assessment of the riboflavin status in human, Experientia 30: 665-667.

Hoffman D. J., 2002, Role of selenium toxicity and oxidative stress in aquatic birds, Aquatic Toxicology. 57(12): $11-26$

Hoffman D. J., Eagles-Smith C. A., Ackerman J. T., Adelsbach T. L. \& Stebbins K. R., 2011, Oxidative stress response of Forster's terns (Sterna forsteri) and Caspian terns (Hydroprogne caspia) to mercury and selenium bioaccumulation in liver, kidney, and brain, Environmental Toxicology and Chemistry 30(4): 920-929.

Hoffman D. J., Henny C. J., Hill E. F., Grove R. A., Kaiser J. L. \& Stebbins K. R., 2009, Mercury and drought along the lower Carson River, Nevada: III. Effects on blood and organ biochemistry and histopathology of snowy egrets and Black-crowned night-herons on Lahontan reservoir, 2002-2006, Journal of Toxicology and Environmental Health A 72(20): 1223-1241.

Hoffman D. J., Spalding M. G. \& Frederick P. C., 2005, Subchronic effects of methylmercury on plasma and organ biochemistries in great egret nestlings, Environ. Toxicol. Chem. 24(12): 3078-3084.

Isaksson C., 2010, Pollution and its impact on wild animals: a meta-analysis on oxidative stress, Ecohealth 7(3): 342-350.

Isaksson C., Johansson A. \& Andersson S., 2008, Egg yolk carotenoids in relation to habitat and reproductive investment in the great tit Parus major, Physiological and Biochemical Zoology 81(1): 112-118.
Isaksson C., Sturve J., Almroth B. C. \& Andersson S., 2009, The impact of urban environment on oxidative damage (TBARS) and antioxidant systems in lungs and liver of great tits, Parus major, Environmental Research 109(1): 46-50.

Kabala C. \& Singh B. R., 2001, Fractionation and mobility of copper, lead, and zinc in soil profiles in the vicinity of a copper smelter, Journal of Environmental Quality 30: 485-492.

Kamiński P., Kurhalyuk N. \& Szady-Grad M., 2007, Heavy metal-induced oxidative stress and changes in physiological process of free radicals in the blood of white stork (Ciconia ciconia) chicks in polluted areas, Polish Journal of Environmental Studies 16(4): 555-562.

Kamiński P., Kurhalyuk N., Jerzak L., Kasprzak M., Tkachenko H., Klawe J. J., Szady-Grad M., Koim B. \& Wiśniewska E., 2009a, Ecophysiological determinations of antioxidant enzymes and lipoperoxidation in the blood of White Stork Ciconia ciconia from Poland, Environmental Research 109: 29-39.

Kamiński P., Kurhalyuk N., Kasprzak M., Jerzak L., Tkachenko H., Szady-Grad M., Klawe J. J. \& Koim B., 2009b, The impact of element-element interactions on antioxidant enzymatic activity in the blood of White Stork (Ciconia ciconia) chicks, Archives of Environmental Contamination and Toxicology 56: 325-337.

Kamiński P., Kurhalyuk N., Kasprzak M., Szady-Grad M. \& Jerzak L., 2006a, Dynamics of chemical elements in the blood of White Stork Ciconia ciconia chicks from polluted environments in Western Poland, [in:] P. Tryjanowski, T. H. Sparks \& L. Jerzak (eds), The White Stork in Poland: Studies in biology, ecology and conservation, Bogucki Wyd. Nauk, Poznań: 353-357.

Kamiński P., Kurhalyuk N., Kasprzak M., Szady-Grad M. \& Jerzak L., 2006b, Element-element interactions in the blood of the White Stork Ciconia ciconia chicks from Poland, [in:] P. Tryjanowski, T. H Sparks, L. Jerzak (eds), The White Stork in Poland: Studies in biology, ecology and conservation, Bogucki Wyd. Nauk, Poznań: 385-394.

Kamyshnikov V. S., 2004, Reference book on clinic and biochemical researches and laboratory diagnostics. MEDpress-inform, Moscow.

Kenow K. P., Hoffman D. J., Hines R. K., Meyer M. W., Bickham J. W., Matson C. W., Stebbins K. R., Montagna P. \& Elfessi A., 2008, Effects of methylmercury exposure on glutathione metabolism, oxidative stress, and chromosomal damage in captive-reared common loon (Gavia immer) chicks, Environmental Pollution 156(3): 732-738.

Koivula J. \& Eeva T., 2010, Metal-related oxidative stress in birds, Environmental Pollution 158: 2359-2370.

Koivula M. J., Kanerva M., Salminen J. P., Nikinmaa M. \& Eeva T., 2011, Metal pollution indirectly increases 
oxidative stress in great tit (Parus major) nestlings, Environmental Research 111(3): 362-370.

Koizumi T., Shirakura H., Kumagai H., Tatsumoto H. \& Suzuki K. T., 1996, Mechanism of cadmium-induced cytotoxicity in rat hepatocytes: cadmium-induced active oxygen-related permeability changes of the plasma membrane, Toxicology 114: 125-134.

Koroliuk M. A., Ivanova L. I., Maiorova I. G. \& Tokarev V. E., 1988, A method of determining catalase activity, Lab Delo 1: 16-19.

Kostiuk V. A., Potapovich A. I. \& Kovaleva Zh. V., 1990, A simple and sensitive method of determination of superoxide dismutase activity based on the reaction of quercetin oxidation, Voprosy Meditsinskoi Khimii 36: 88-91.

Kurhalyuk N., Kamiński P., Kasprzak M. \& Jerzak L., 2006a, Antioxidant enzymes activity and lipid peroxidation processes in the blood of White Stork Ciconia ciconia chicks from Western Poland, [in:] P. Tryjanowski, T. H. Sparks, L. Jerzak (eds), The White Stork in Poland: Studies in biology, ecology and conservation, Bogucki Wyd. Nauk, Poznań: 395-406.

Kurhalyuk N., Kamiński P., Kasprzak M. \& Jerzak L., $2006 \mathrm{~b}$, Induction of reactive species and antioxidant defence systems in the blood of White Stork Ciconia ciconia chicks from different environments in Poland, [in:] P. Tryjanowski, T. H. Sparks, L. Jerzak (eds), The White Stork in Poland: Studies in biology, ecology and conservation, Bogucki Wyd. Nauk, Poznań: 343-352.

Latus C., Kujawa K. \& Glemnitz M., 2000, The influence of landscape structure on White stork's Ciconia ciconia nest distribution, Acta Ornitologica 35: 97-102.

Levine R. L., Garland D., Oliver C. N., Amici A., Climent I., Lenz A.-G., Ahn B.-W., Shaltiel S. \& Stadtman E. R., 1990, Determination of carbonyl content in oxidatively modified proteins, Methods in Enzymology 186: 465-478.

Martinez-Gomez C., Vethaak A. D., Hylland K., Burgeot T., Kohler A., Lyons B. P., Thain J., Gubbins M. J. \& Davies I. M., 2010, A guide to toxicity assessment and monitoring effects at lower levels of biological organization following marine oil spills in European waters, ICES Journal of Marine Science 67(6): 1105-1118.

Martinez-Haro M., Green A. J. \& Mateo R., 2011, Effects of lead exposure on oxidative stress biomarkers and plasma biochemistry in waterbirds in the field, Environmental Research 111(4): 530-538.

Mateo R. \& Hoffman D. J., 2001, Differences in oxidative stress between young Canada geese and mallards exposed to lead-contaminated sediment, Journal of Toxicology and Environmental Health A 64(7): 531-545.

Mateo R., Beyer W. N., Spann J. W., Hoffman D. J. \& Ramis A., 2003, Relationship between oxidative stress, pathology, and behavioral signs of lead poisoning in mallards, Journal of Toxicology and Environmental Health A 66(14): 1371-1389.

Meister A., 1994, The glutathione-ascorbic acid antioxidant systems in animal, Journal of Biological Chemistry 269: 9397-9400.

Moin V. M., 1986, A simple and specific method for determining glutathione peroxidase activity in erythrocytes, Lab. Delo 12: 724-727.

Nowakowski J. J. \& Wasilewska B., 2006, The relationship between spatial distribution, intrapopulation competition and the reproduction parameters of White Stork Ciconia ciconia in the southern basin of the Biebrza river during the years 1994-1999, [in:] P. Tryjanowski, T. H. Sparks, L. Jerzak (eds), The White Stork in Poland: Studies in biology, ecology and conservation, Bogucki Wyd. Nauk, Poznań: 99-113.

Nowakowski J. J., 2003, Habitat structure and breeding parameters of White stork Ciconia ciconia population in Kolno Upland (NE Poland), Acta Ornitologica 38: 39-46.

Nowakowski J. J., 2006, The influence of weather and intrapopulation competition on breeding success of the White stork Ciconia ciconia population in the southern basin of the Biebrza rive valley, [in:] P. Tryjanowski, T. H. Sparks, L. Jerzak (eds), The White Stork in Poland: Studies in biology, ecology and conservation, Bogucki Wyd. Nauk, Poznań: 143-160.

Orłowski G., Polechoński R., Dobicki W., Dolata P. \& Bednarska M., 2006, Heavy metal concentrations in feathers of White stork Ciconia ciconia nesting in Central Poland: methodological implications for further ecotoxicological studies, [in:] P. Tryjanowski, T. H. Sparks, L. Jerzak (eds), The White Stork in Poland: Studies in biology, ecology and conservation, Bogucki Wyd. Nauk, Poznań: 237-247.

Profus P., 1991, The breeding biology of the White stork Ciconia ciconia (L.) in the selected area of Southern Poland, Studia Nat. A 37: 11-57.

Profus P., 2006, Population changes and breeding ecology of the White Stork Ciconia ciconia L. in Poland against a background of the Europian population. Synthesis. Studia Nat. 50: 1-155.

Rainio M. J., Kanerva M., Salminen J. P., Nikinmaa M. \& Eeva T., 2013, Oxidative status in nestlings of three small passerine species exposed to metal pollution, Science of the Total Environment 454-455: 466-473.

Rana S. V., Allen T. \& Singh R., 2002, Inevitable glutathione, then and now, Indian Journal of Experimental Biology 40(6): 706-716.

Ravin H. A., 1961, An improved colorimetric enzymatic assay of ceruloplasmin, Journal of Laboratory and Clinical Medicine 58: 161-168.

Sies H., 1999, Glutathione and its role in cellular functions, Free Radical Biology Medicine 27: 916-921. 
Stadtman E. R. \& Berlett B. S., 1997, Reactive oxygen-mediated protein oxidation in aging and disease, Chemical Research in Toxicology10: 485-494.

Thomas D. J., Thomas J. B., Prier S. D., Nasso N. E. \& Herbert S. K., 1999, Iron superoxide dismutase protects against chilling damage in the cyanobacterium Symechococcus species PCC7942, Plant Physiology 120: 275-282.

Tryjanowski P., Jerzak L. \& Radkiewicz J., 2005, Effect of water level and livestock on the productivity and numbers of breeding white storks, Waterbirds 28: 378-382.

Tryjanowski P., Sparks T. H. \& Jerzak L., 2006, White stork Ciconia ciconia research in Poland: where we are and where we are going?, [in:] P. Tryjanowski, T. H. Sparks, L. Jerzak (eds) The White Stork in Poland: Studies in biology, ecology and conservation, Bogucki Wyd. Nauk, Poznań: 7-14.
Valko M., Morris H. \& Cronin M. T., 2005, Metals, toxicity and oxidative stress, Current Medicinal Chemistry 12: 1161-1208.

Van Kuijk F. J. G. M., Sevanian A., Handelman G. J. \& Dratz E. A., 1987, A new role for phosholipase A2: protection of membranes from lipid peroxidation damage, Trends in Biochemical Sciences 12: 31-34.

Yeh Ch.-Ch., Barr G., Powell Ch. A., Mesia-Vela S., Wang Y., Hamade N. K., Austin J. H. M. \& Santell R. M., 2008, No effect of cigarette smoking dose on oxidized plasma proteins, Environmental Research 106: 219225.

Zar J. H., 1999, Biostatistical analysis, Prentice-Hall, Englewood Cliffs, New Jersey. 